\title{
Pattern of Pink Bollworm Diapaused Larval Exit from the Last Season Cotton Bolls and Their Biological Parameters
}

\author{
Mervat H. A. Metayi 1
}

\begin{abstract}
The present study was carried out to investigate the patterns of pink bollworm (PBW), Pectinophora gossypiella, diapaused larval exit from cotton bolls, percent larval mortality after leaving bolls and the development as well as some biological parameters of living larvae. Diapaused larval exit began at March and the number of emerged larvae from immature green cotton bolls that collected from El-Behira (ranged from 22.3 to 106.7 larvae) is significantly higher than the number of emerged larvae from immature green cotton bolls that collected from Alexandria (numbers ranged from 17.7 to 82.3 larvae) during the investigated period. Percent larval mortality in exited larvae at March, April and May from Alexandria cotton bolls $(70.3,64.7$ and $52.1 \%$, respectively) is significantly higher than the percent larval mortality from El-Behira (66.5, 57.8 and $46.4 \%$, respectively). The PBW \%adult emergence in El-Behira strain is significantly higher than the PBW percent of adult emergence in Alexandria strain during March and April. Fecundity (No. laid eggs / female) and fertility (percent egg hatching) are significantly higher in the moths which emerged from ElBehira strain than from Alexandria strain. This study represents important information about the pattern of PBW diapaused larval exit from the last season cotton bolls which can help in the $P B W$ infestation prediction and mangement.
\end{abstract}

Keywords: Pectinophora gossypiella, Diapause, Biological parameters.

\section{INTRODUCTION}

The pink bollworm, Pectinophora gossypiella (Saunders) (Lepidoptera: Gelechiidae) is considered to be one of the most injurious cotton pests. It was described in 1843 from specimens damaging cotton in India (Noble, 1969). From India the pink bollworm apparently reached Egypt in infested cottonseed shipped in 1906 or 1907, and subsequently reached the western hemisphere in infested cottonseed shipped from Egypt to Mexico between 1911 and 1913 (White, 1960). Under cool dry conditions, $P$. gossypiella larvae may undergo diapause in a small cocoon in partially opened bolls in cotton lint, stored seed or in the soil. This cycle, particularly if entered into late in the season after cold weather begins, ordinarily lasts until the following cotton crop is again fruiting. Only a small part of the overwintering population survives to infest cotton of the following year (Beasley and Adams, 1995). Several sprays have been needed for its control, which leads to outbreaks of secondary pests, otherwise regulated by natural enemies (Lykouressis et al., 2005).

The heavy use of pesticides, besides, creating problems of health hazards, and environmental pollution has also resulted in the development of insect resistance to insecticides (Ahmad and Khan, 1991; Sorejani, 1998), and elimination of natural biological control agents (Hamburg and Guest, 1997; Hendi et al., 2016), consequently, upsetting the natural balance of these insect pests. But, hatching PBW larvae can penetrate flowers or bolls within 20-30 min (Hutchison et al., 1988) or within $2 \mathrm{~h}$ (Ingram, 1994). Therefore, timing of insecticides spraying affects the insect control process. So, the time of PBW larval exit from the last season cotton bolls and its development has become extremely important. This can help in the PBW infestation prediction and management. Therefore, the present study was carried out to investigate the pattern of diapause larval exit from cotton bolls, \%larval mortality after leaving bolls, the development and some biological parameters of living larvae.

\section{MATERIALS AND METHODS}

\section{Cotton bolls collection:}

Two thousand immature green cotton bolls were collected from each El-Amria, Alexandria governorate and Abou-Elmatameer city, Elbehira governorate cotton fields at October 2015. The immature green bolls from each place were transferred to the laboratory and each was divided to 4 groups (500 green bolls each) and kept in ventilated place. Bolls were first examined for PBW emergence in March 1, 2016 and weekly thereafter until 1 July. All living and dead larvae and pupae and adults were recorded. Living larvae and pupae were collected and placed individually in 28-ml capacity glass cups with about $15 \mathrm{ml}$ of agar base artificial PBW diet (Rashad and Ammar, 1985) to provide moisture. Glass cups were examined each week for mortality and the \% larval mortality was calculated. The living larvae were followed to pupation and adult emergence. Adults were sexed and placed in glass cups provided with a folded sheet paper as oviposition site. Two adult males were kept with one adult female to maximize the probability of successful mating. Laid eggs were counted and followed until hatching. The \%pupation, \%adult emergence, fecundity (No. laid eggs / female) and fertility (\%egg hatching) also were calculated. 


\section{Statistical Analysis:}

Average numbers of dead larvae and dead pupae on each sampling month were recorded and percentage mortalities of the total numbers of PBW for each month calculated. All data were replicated four times and the values are expressed as mean \pm standard error. The SAS 8.0 software was used for analysis of the data and the means were tested for significant differences using analysis of variance (ANOVA) test (LSD at $\mathrm{P}<0.05$ ) (SAS Statistical software, 1999).

\section{RESULTS AND DISCUSSION}

The PBW is considered to be one of the most injurious cotton pests, because it is difficult to control with insecticides (Lykouressis et al., 2005; Metayi et al.,2015). The infestation of cotton bolls by the PBW larvae was initiated by moths emerged from overwintered larvae (Slosser and Watson, 1972). Therefore, adopting an IPM program for PBW control is very important. The prediction of diapaused larval that exit from the last cotton season and the infestation of the present cotton season is an important part of the IPM program of PBW. In the present study, diapaused larval exit began at March and numbers ranged from 17.7 to 82.3 at Alexandria and from 22.3 to 106.7 at El-Behira during the investigated period from March to July (Table 1). It is also clear that, the number of emerged larvae from immature green cotton bolls collected from El-Behira was significantly higher than the number of emerged larvae from immature green cotton bolls collected from Alexandria. The Percent of larval mortality in exit larvae from Alexandria cotton bolls was significantly higher than the percent larval mortality from El-Behira cotton bolls during March, April and May. While the \%larval mortalities in exit larvae from El-Behira cotton bolls were 66.5, 57.8, 46.4, 45.2 and $18.6 \%$ of larvae exiting at March, April, May, June and July, respectively. The \%larval mortalities in exit larvae from Alexandria cotton bolls were 70.3, 64.7, 52.1, 47.9 and $15.2 \%$ of larvae exiting at the same periods, respectively (Table 2 ).

Percent pupation of PBW larvae did not significantly differ between Alexandria strain and El-Behira strain during the investigation period. The \%pupation ranged between 54.0 to $69.4 \%$ at Alexandria and 52.2 to $65.2 \%$ at El-Behira at the study period (Table 3). The percent of emerged adult in El-Behira strain was significantly higher than the PBW \%adult emergence in Alexandria strain during March and April. The statistical analysis showed no difference in adult emergence between the two strains during May, June and July (Table 4). Fecundity (No. laid eggs / female) and fertility (\%egg hatching) are significantly higher in the moths which emerged from El-Behira strain than from Alexandria strain (Tables 5 and 6). The number of laid eggs / female was ranged from 180.5 to 290.6 in Alexandria strain and ranged from 195.5 to 366.8 in El-Behira strain during the investigation period (Table 5).

Table 1. Number of live diapausing pink bollworm larvae emerged from immature green cotton bolls collected from Alexandria and El-Behira governorates

\begin{tabular}{llllll}
\hline \multirow{2}{*}{ Location } & \multicolumn{5}{c}{ No. emerged larvae at different dates \pm SE } \\
\cline { 2 - 5 } & March & April & May & June & July \\
\hline Alexandria & $30.0 \mathrm{~b} \pm 1.8$ & $74.5 \mathrm{~b} \pm 5.1$ & $80.3 \mathrm{~b} \pm 4.7$ & $82.3 \mathrm{~b} \pm 3.5$ & $17.7 \mathrm{~b} \pm 1.3$ \\
El-Behira & $41.0 \mathrm{a} \pm 2.4$ & $92.3 \mathrm{a} \pm 4.3$ & $91.7 \mathrm{a} \pm 6.4$ & $106.7 \mathrm{a} \pm 5.8$ & $22.3 \mathrm{a} \pm 1.9$ \\
\hline
\end{tabular}

Numbers within a column with a letter in common are not significantly different according to analysis of variance (ANOVA) test (LSD at $\mathrm{P}<0.05$ ).

Table 2. Mortality percent of pink bollworm larvae after emergence from immature green cotton bolls collected from Alexandria and El-Behira governorates

\begin{tabular}{llllll}
\hline \multirow{2}{*}{ Location } & \multicolumn{4}{l}{ Mortality (\%) of emergened larvae at different dates \pm SE } & \multirow{2}{*}{ July } \\
\cline { 2 - 6 } & March & April & May & June & $15.2 \mathrm{a} \pm 1.2$ \\
\hline Alexandria & $70.3 \mathrm{a} \pm 4.5$ & $64.7 \mathrm{a} \pm 3.1$ & $52.1 \mathrm{a} \pm 2.5$ & $47.9 \mathrm{a} \pm 3.5$ & $18.6 \mathrm{a} \pm 1.5$ \\
El-Behira & $66.5 \mathrm{~b} \pm 2.6$ & $57.8 \mathrm{~b} \pm 2.8$ & $46.4 \mathrm{~b} \pm 2.2$ & $45.2 \mathrm{a} \pm 2.6$ & \\
\hline
\end{tabular}

Numbers within a column with a letter in common are not significantly different according to analysis of variance (ANOVA) test (LSD at $\mathrm{P}<0.05)$.

Table 3. \%Pupation of pink bollworm larvae after emergence from immature green cotton bolls collected from Alexandria and El-Behira governorates

\begin{tabular}{llllll}
\hline \multirow{2}{*}{ Location } & \multicolumn{2}{l}{$\%$ Pupation of pink bollworm larvae at different dates \pm SE } & \multirow{2}{*}{ July } \\
\cline { 2 - 5 } & March & April & May & June & $69.4 \mathrm{a} \pm 4.3$ \\
\hline Alexandria & $54.0 \mathrm{a} \pm 3.2$ & $63.4 \mathrm{a} \pm 4.2$ & $67.8 \mathrm{a} \pm 3.9$ & $70.3 \mathrm{a} \pm 5.8$ & $65.2 \mathrm{a} \pm 3.7$ \\
El-Behira & $52.2 \mathrm{a} \pm 3.8$ & $67.9 \mathrm{a} \pm 5.1$ & $70.5 \mathrm{a} \pm 3.7$ & $68.6 \mathrm{a} \pm 3.6$ & \\
\hline
\end{tabular}

Numbers within a column with a letter in common are not significantly different according to analysis of variance (ANOVA) test (LSD at $\mathrm{P}<0.05)$. 
The percent of egg hatching was ranged from 67.1 to $76.5 \%$ in Alexandria strain and was ranged from 71.3 to $81.7 \%$ in El-Behira strain during the investigation period (Table 6).

Although it may not be obvious in many insects, diapause does not entail a complete cessation of development. As evidenced by characteristic temporal patterns of gas exchange, nutrient metabolism, stress resistance, and gene expression, diapause is a dynamic process. Besides that, environmental and hormonal regulators of diapause have been reasonably well defined (Denlinger, 2002; Hodek, 2002). Diapausing insects pass through a graded series of physiologically distinct developmental stages including induction, preparation, initiation, maintenance, termination, and sometimes post-diapause quiescence (Kostal, 2006). The termination of diapause is accompanied by a rapid decline in expression of the diapause-upregulated genes and, conversely, an elevation in expression of many genes that were downregulated during diapauses (Denlinger, 2002). Results of the present study indicated increasing in the mortality percentages of the exit diapused larvae, a lower fecundity and lower fertility. It has been recorded previously a lower post-diapause survival and reduced fecundity (Ellers and van Alphen, 2002; Williams et al., 2003; Munyiri et al., 2004; Matsuo, 2006).

Table 4. Percent of adult emergence of pink bollworm from pupae after emergence from immature green cotton bolls collected from Alexandria and El-Behira governorates

\begin{tabular}{llllll}
\hline \multirow{2}{*}{ Location } & \multicolumn{2}{l}{$\%$ Adult emergence of pink bollworm at different dates \pm SE } & July \\
\cline { 2 - 5 } & March & April & May & June & $48.7 \mathrm{a} \pm 3.6$ \\
\hline Alexandria & $30.2 \mathrm{~b} \pm 2.5$ & $45.6 \mathrm{~b} \pm 3.8$ & $55.4 \mathrm{a} \pm 2.9$ & $50.8 \mathrm{a} \pm 4.3$ & $53.4 \mathrm{a} \pm 4.7$ \\
El-Behira & $39.5 \mathrm{a} \pm 2.1$ & $51.8 \mathrm{a} \pm 4.1$ & $53.1 \mathrm{a} \pm 3.5$ & $56.2 \mathrm{a} \pm 2.9$ & \\
\hline
\end{tabular}

Numbers within a column with a letter in common are not significantly different according to analysis of variance (ANOVA) test (LSD at $\mathrm{P}<0.05)$.

Table 5. Fecundity of pink bollworm adults emerged from immature green cotton bolls collected from Alexandria and El-Behira governorates

\begin{tabular}{|c|c|c|c|c|c|}
\hline \multirow[t]{2}{*}{ Location } & \multicolumn{3}{|c|}{ Fecundity (No. laid eggs / female) $\pm \mathrm{SE}$} & \multirow[b]{2}{*}{ June } & \multirow[b]{2}{*}{ July } \\
\hline & March & April & May & & \\
\hline Alexandria & $180.5 \mathrm{~b} \pm 15.5$ & $185.2 \mathrm{~b} \pm 8.6$ & $224.0 \mathrm{~b} \pm 14.5$ & $295.5 \mathrm{~b} \pm 23.0$ & $290.6 \mathrm{~b} \pm 16.3$ \\
\hline El-Behira & $200.3 \mathrm{a} \pm 17.3$ & $195.5 \mathrm{a} \pm 13.8$ & $260.8 \mathrm{a} \pm 18.2$ & $370.5 \mathrm{a} \pm 27.4$ & $366.8 \mathrm{a} \pm 13.8$ \\
\hline
\end{tabular}

Numbers within a column with a letter in common are not significantly different according to analysis of variance (ANOVA) test (LSD at $\mathrm{P}<0.05)$.

Table 6. Fertility of pink bollworm adults emerged from immature green cotton bolls collected from Alexandria and El-Behira governorates

\begin{tabular}{|c|c|c|c|c|c|}
\hline \multirow[t]{2}{*}{ Location } & \multicolumn{3}{|c|}{ Fertility (\%egg hatching) $\pm \mathrm{SE}$} & \multirow[b]{2}{*}{ June } & \multirow[b]{2}{*}{ July } \\
\hline & March & April & May & & \\
\hline Alexandria & $69.5 \mathrm{a} \pm 3.2$ & $67.1 \mathrm{~b} \pm 2.9$ & $74.2 \mathrm{~b} \pm 2.7$ & $76.5 \mathrm{a} \pm 2.7$ & $75.0 \mathrm{~b} \pm 1.9$ \\
\hline El-Behira & $71.3 \mathrm{a} \pm 2.8$ & $73.7 \mathrm{a} \pm 1.6$ & $81.7 \mathrm{a} \pm 2.0$ & $80.2 \mathrm{a} \pm 3.2$ & $81.5 \mathrm{a} \pm 2.5$ \\
\hline
\end{tabular}

Numbers within a column with a letter in common are not significantly different according to analysis of variance (ANOVA) test (LSD at $\mathrm{P}<0.05$ ).
Finally, PBW is the key pest in the cotton-producing several ways. In severe infestations, damaged squares of reduced yield on the plant itself. The preferred food of the larva is the kernel of the seed. Usually the tiny under the inner surface of the covering, making a typical seed. It devours the inside of the seed; then the small passes through it. Many larvae are heavy feeders and eat reach maturity (Lohag and Nahyoon, 1995, Ahmad et al., 2003). The high costs of chemical control, and environmental considerations suggest the need for Extensive research has emphasized the need for early monitoring, biological control, cultural, behavioural, as a base for the formulation of integrated PBW management systems (Henneberry and Naranjo, 1998). This study represent an important information which can help in the PBW infestation prediction and implementation of IPM programs. 


\section{REFERENCES}

Ahmad M. and M.R. Khan. 1991. Insecticide resistance management strategies in cotton pests in Pakistan. Pak. Entomol. 13: 1-4.

Ahmad, M., M.I. Arif and Z. Ahmad. 2003. Susceptibility of Helicoverpa armigera (Lepidoptera: Noctuidae) to new chemistries in Pakistan. Crop Prot. 22: 539-544.

Beasley C.A. and C.J. Adams. 1995. Effects of irrigation, irrigation timing, and cotton boll burial on extent and patterns of pink bollworm spring emergence. Southwestern Entomologist. 20:73-106.

Denlinger, D.L. 2002. Regulation of diapause. Annual Review of Entomology. 47: 93-122.

Ellers J. and J.M.van Alphen. 2002. A trade-off between diapause duration and fitness in female parasitoids. Ecolog. Entomology 27, 279-284.

Hamburg H.V. and P.J. Guest. 1997. The impact of insecticide arthropods in cotton agro-ecosystem in South Africa. Archives Environ. Contamin. Toxic. 32: 63-68.

Hendi,R.A. H..A.Moussa, and E.M. Hegazi.2016. Effects of Dimilin on Young Spodoptera littoralis (Boisd.) Larvae.Alex.Sci.Exch.J.37(2):133-138.

Henneberry T.J. and S.E. Naranjo. 1998. Integrated management approaches for pink bollworm in the southwestern United States. Integrated Pest Management Reviews. 3: 31-52.

Hodek, I. 2002. Controversial aspects of diapause development. European Journal of Entomol. 99: 163-173.

Hutchison, W.D., C.a. Beasley, T.J. Henneberry, and J.M. Martin. 1988. Sampling pink bollworm (Lepidoptera: Gelechiidae) eggs: for improved timing and reduced use of insecticides. J. Econ. Entomol. 81: 673-678.

Ingram, W.R. 1994. Pectinophora (Lepidoptera: Gelechiidae). In: Matthews, G.A., Tunstall, J.P. (Eds.), Insect Pests of Cotton. University Press, Cambridge, pp. 107-150.

Kostal, V. 2006. Eco-physiological phases of insect diapause. J. Insect Physiolo. 52: 113-127.
Lohag M.G.M. and Y.M. Nahyoom. 1995. Comparative efficacy of Hostathion ${ }^{\circledR}$, Sumicidin ${ }^{\circledR}$ and Sevin ${ }^{\circledR}$ against cotton bollworms. J. Agric. Res. 13: 963-368.

Lykouressis, D., D.Perdikis , D. Samartzis , A. Fantinou and S. Toutouzas . 2005. Management of the pink bollworm Pectinophora gossypiella (Saunders) (Lepidoptera: Gelechiidae) by mating disruption in cotton fields. Crop Prot. 24: 177-183.

Matsuo, Y. 2006. Cost of prolonged diapause and its relationship to body size in a seed predator. Functional Ecology 20: 300-306.

Metayi, M.H. A. , M.A. M. Ibrahiem, and D. A. ElDeeb.2015. Toxicity and Some Biological Effects of Emamectin Benzoate, Novaluron and Diflubenzuron against Cotton Leafworm.Alex.Sci.Exch.J.36(4):350-357.

Munyiri, F.N., Y.Shintani and Y. Ishikawa. 2004. Evidence for the presence of a threshold weight for entering diapause in the yellow-spotted longicorn beetle, Psacothea hilaris. Journal of Insect Physiolo. 50: 295-301.

Noble, L.W. 1969. Fifty years of research on the pink bollworm in the United States. USDA Agr. Hndbk. 357.62 pp.

Rashad A.M. and E.D. Ammar. 1985. Mass rearing of the spring bollworm, Earias insulana (Boisd.) on semiartificial diet. Bull. Soc. Ent. Egypte. 65: 239 - 242.

SAS Institute, Inc. (1999). PC-SAS users guide, Version 8. North Carolina statistical analysis system Institute, Inc.

Slosser J.E. and T.F. Watson. 1972. Population growth of the pink bollworm. Arizona Agricultural Experiment Station Bulletin. 195: 32 - 45.

Sorejani, M. 1998. Current trend in pesticide usage in some Asian countries. Envior. Impelic. Res. Pest Intern. Atomic Energy Agency. Vienna Austria. 219-234.

White, R.W. 1960. History of pink bollworm infestation in the United States 19 17-1959. USDA, Agric. Res. Serv. Plant Pest Control Div., unpublished report.

Williams, J.B., J.D. Shorthouse and R.E. Lee. 2003. Deleterious effects of mild simulated overwintering temperatures on survival and potential fecundity of rosegalling Diplolepis wasps (Hymenopetra:Cynipidae). Journal of Experim. Zoology 298A, 23-31. 


$$
\text { الملخص العربي }
$$

\section{نمط خروج اليرقات الساكنة لدودة اللوز القرنفلية من لوزالموسم السابق لمحصول القطن وبعض العوامل} البيولوجيه لها

$$
\text { ميرفت حسنين ابو الحمد مطاوع }
$$

التى خرجت من اللوز فى سـلالة محافظة البحيره (1.7.7،

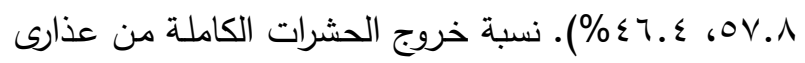
سلالة محافظة البحيره كانت أكبر وبصوره معنوية من نسبة خروج الحشرات الكاملة من عذارى سلالة محافظة الأسكندرية خـلال شـهرى مـارس وأبريـل. عدد البيض الذى تم وضـعه/ أنتى فراشـة وكذللك نسبة فقس البيض فـى فراشـات سـلالة محافظة البحيره كان أعلى بصوره معنوية من فراشـات سلالة

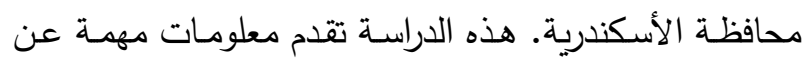
نمـط خـروج يرقـات دودة اللـوز القرنفليـة السـاكنة فـى اللـوز الأخضر الغير ناضـج لمحصول القطن من الموسم السابق التى يمكن أن تساعد فى التتبأ بدرجه الإصـابة بدودة اللوز

القرنفلية وتحديد الاستراتيجيه المناسبه لمكافحتها.
تم إجراء هذ البحث بهدف دراسـة نمط خروج يرقات دودة اللوز القرنفلية الساكنة فى لوز محصول القطن من الموسم السابق، نسب مسوت اليرقـات بعد خروجهـا، بالإضـافة إلىى

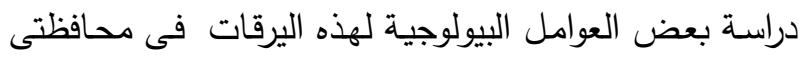
الأسكندرية والبحيره. بدأ خروج اليرقات فى شهر مارس تتراوح عدد اليرقـات الذنى خـرج مـن اللـوز الأخضر الغير ناضــ

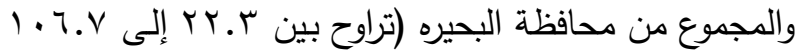
يرقه) أكبر بصوره معنويـة من عدد اليرقات الذى خرج من اللوز الأخضر الغير ناضـج المجموع من محافظة الأسكندريه (تراوح بين V.V V إلى r. V. يرقه) أثناء فترة الدراسـة. نسبة مـوت اليرقـات التى خرجـت مـن اللـوز فـى سـلالة محافظـة

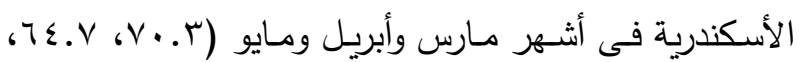
(. r\% r\%) كانت أعلى بصوره معنوية من نسبة موت اليرقات 